\title{
Cleaner Production in Rectilinear Knitting for Fashion Clothing
}

\author{
Ana Paula Gentile, Francisca Dantas Mendes* \\ School of Arts, Sciences and Humanities, University of São Paulo, São Paulo, Brazil
}

Copyright $\bigcirc 2018$ by authors, all rights reserved. Authors agree that this article remains permanently open access under the terms of the Creative Commons Attribution License 4.0 International License

\begin{abstract}
Research related to fashion clothing and interconnected to a cleaner production are increasingly relevant, for the textile chain is largely complex and linked to innumerous factors relating to environmental pollution. Viewing to add improvements in the process or product, the cleaner production seeks the solution by improving some processes that guide these paths. This article aims to study the possibilities of cleaner production in rectilinear knitting for fashion clothing.
\end{abstract}

Keywords Cleaner Production, Rectilinear Knitting, Environmental Impact

\section{Introduction}

The constant concern about processes that result in the environmental impact is growing. The garment industry and the textile sector are largely complex and rely on this consumption of innumerable resources to transform materials into products. The main objective of this article is to study the minimization of raw materials in the textile sector, arising from the possibility of research visualized in the rectilinear knitting segment through Cleaner Production.

According to Pezzolo [1], the knitted fabric is the result of the interlacing of one or more yarns that can be produced manually or with the help of machines, where these yarns take the form of loops that support each other, thus characterizing an important aspect that results in flexibility among others.

Cardoso [2] argues that the design of the product should be thought of in a way to satisfy usability needs as well as in its projection, aiming at materials that are less impacting to the environment and at the same time prolonging the product life cycle.
The cleaner production has as its intention to track alternatives that minimize or avoid consumption in several stages of the production process, seeking to bring improvements that satisfy the production (Jabbour, Jabbour [3]. This article presents considerations regarding cleaner production focusing on the reduction of solid textile waste.

\section{Cleaner Production}

Cleaner Production is a methodology created to minimize environmental problems, used as a tool to reduce pollution, in which company managers seek solutions that guide the management of natural resources (BERKEL, 2000 apud ANACLETO et al, [4]).

Giannetti and Almeida [5] claim that "Cleaner production is the continuous application of an integrated environmental prevention strategy to processes, products and services to increase production efficiency and reduce risks to humans and the environment."

According to Berkel (2006) cited in Anacleto et al [4] It is essential and simple to Cleaner Production to reduce emission and waste during the accomplishment of a task or product and not treat it after it has already been generated.

These authors contemplate that the improvement in the productive process, seeking for efficiency and actions that do not aggressively reach the human being are considered cleaner production, yet protecting the environment.

According to Jabbour and Jabbour [3] Cleaner Production is a methodology that aims to show and quantify the generation of solid waste as well as liquid effluents and / or atmospheric emissions with the intention of reaching alternatives that reduce or avoid the consumption of water, energy and raw materials. 


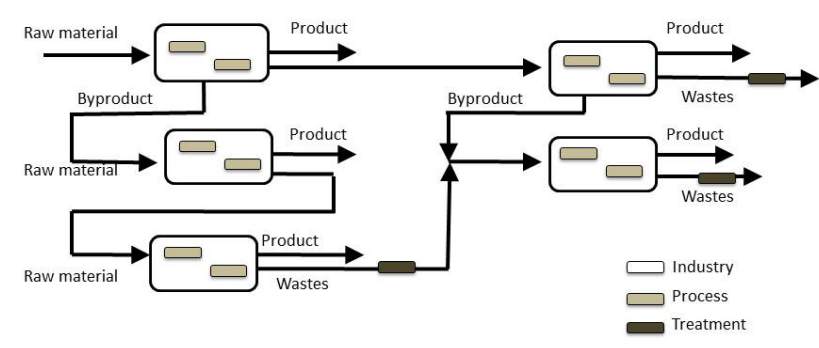

Source: Giannetti and Almeida [5]

Figure 1. Representation of the interaction between the flows of different systems

The figure above shows the possibilities of interaction among companies in a way that they can use as raw material what is considered disposal by the other.

According to studies, the National Cleaner Production Centers were created in 1995 and after twenty years of its implementation, it was verified that expectations were fulfilled and that changes would be necessary to reach the fragile points. In general, the program was carried out successfully, since expectations were satisfactorily fulfilled in their majority, and even unexpected activities took place, such as the creation of networks at the regional and then national levels. From the perspectives not reached we have the implementation of production centers in partnership with technological facilities of pollution control to verify the environmental quality. It is intended to accomplish them in the totality and extend the program in a meaningful way. (LUKEN et all [6])

According to data from Luken et al [6], Brazil has been part of the project since 1995 with SENAI as the production center. It shows that this country seeks to encourage cleaner production from the outset.

However, before this date it had already discussed in the country in relation to the environment. For instance, in Dias [7] and in Luken et al [6] there are data of the "United Nations Conference on Environment and Development (UNCED)" which took place in Rio de Janeiro in 1992. The conference focused on the signing of five documents in order to discuss about the environment and its settings for the following years. According to Cardoso [2], the environmental movement began to take shape and showed itself in what it is known today. It became consolidated from the institutional point of view, starting with the second UN conference in 1992 in Rio de Janeiro, thus becoming part of the world political scenario.

The justification for investing in cleaner production is due to the fact that it economically strengthens the industry through the prevention of pollution, driven by the desire to contribute to a better environmental situation in a certain region (SENAI [8]).

Ribeiro, cited in Senaga [9], discusses "the benefits of cleaner production in micro, small and medium-sized companies", and after briefly reviewing the evolution of corporate environmental behavior, claims that the traditional approach based on corrective control has been outdated by its limitations and replaced by the preventive approach that proves more efficient, since it seeks causalities of environmental problems.

Ribeiro also concludes that the success of cleaning production is justified because it is more efficient, leading to minimization of the use of raw materials, water and also the generation of waste, among others, besides making use of less toxic materials.

Based on the known environmental problems, the cleaning production program aims to verify the activities of a company as well as its production process, raising studies of the problem in relation to the use of materials and energy. (SENAI, [8])

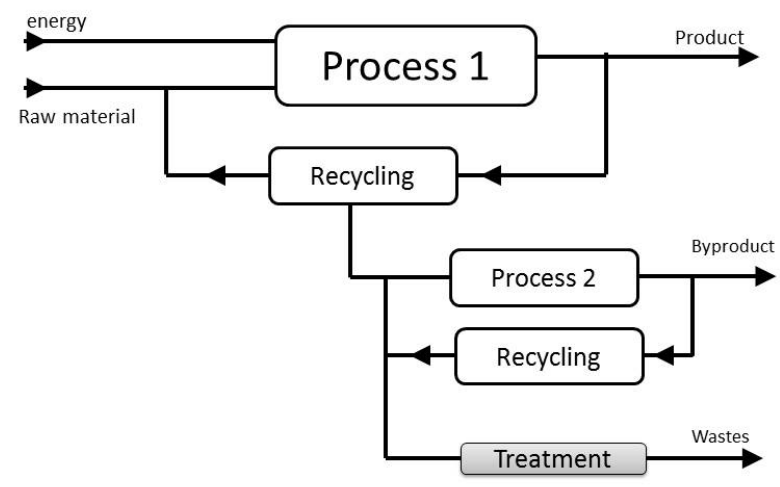

Source: Giannetti and Almeida [5]

Figure 2. Representation of a company where the concept of cleaning production is applied

According to Giannetti and Almeida [5], the figure above:

"Consists of optimizing isolated processes and making materials, such as water and raw materials, circulate as much as possible within the process before discard, resulting in a better utilization of raw material and energy" GIANNETTI \& ALMEIDA, 2006, $p 14$ [5].

Ribeiro (cited in Senaga [9]), recalls that many corporations have been admitting cleaner production as business strategy, having as their central benefit the environmental suitability with reduced cost, improved environmental performance and also the company's image. He emphasizes the advantage to small and medium-sized companies in relation to the facility to test the processes or modify them. He concludes that cleaner production aims to improve environmental quality in the state of São Paulo.

This debate drives innovations within corporations for the purpose of putting them into a sustainable development. From this point on, the studies of the products of technologies and materials are led with a view to the waste reduction and to discover ways to reuse them (SENAI, [8]). 


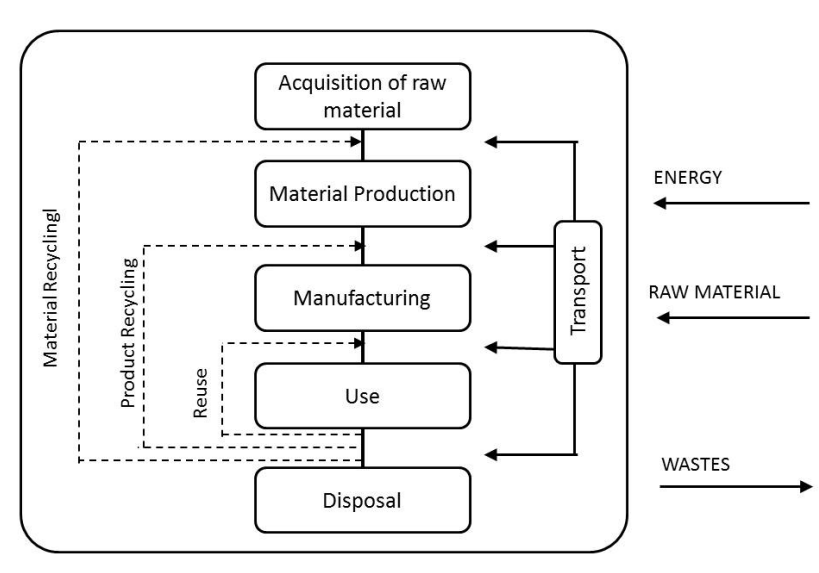

Source: Giannetti and Almeida [5]

Figure 3. The main stages of a product's life cycle

According to Giannetti and Almeida [5] reuse, product and material recycling should be associated with the life cycle of the product, as seen in figure 3 .

Cleaner production has some reasons for its implementation, such as: lower production costs, final disposal, health care and a cleaner environment. It still brings an improvement in process efficiency and product quality, influencing the innovative industrial contribution and competitiveness. It entails a reduction of risks to workers, consumers of products and the community including the future generations. Finally, it provides the improvement in the public concept of corporations bringing intangible social and economic benefits (SENAI [8]).

\subsection{Cleaner Production in the Textile Sector}

The sales in Brazil are over US \$ 21 billion per year in relation to the fashion sector. The country is in second place among worldwide indigo suppliers. In the segment of knitwear it finds itself as third supplier, in the manufacture is in fifth position and in the distribution of yarns, filaments and fabrics, it is in the eighth position, possessing one of the largest worldwide industrial parks (SEBRAE [10]).

Between 2001 and 2011 a global growth of 43.2\% occurred in the production of textiles in Brazil, while international trade in textiles and clothing increase of 2.1 times. In the knitting segment there is a fabric production average of 615,352 (ton) between 2008 and 2012 (IEMI [11]).

According to Banning; Gam (2011) cited in Zonatti et al [12] many environmental problems are created by the textile and clothing industry, such as the large amount of waste arising from the entire manufacturing process.

An innovation is expected in this industry, but for this the criteria should be more rigorous when it comes to detailed knowledge of the production of its supplies and consumption. The impact on the environment is increasingly linked to products, machinery, inputs, processes, forms and methods of work organization. (Bruno et al (2009) cited in Faria; Pacheco [13])

The insertion of environmental management in the textile industries is considered important, since it strengthens the beneficial relationship between the production of the product and the environment. The Cleaner Production has been highlighted by the fact that it is a tool used as an Environmental Management improvement in a corporation bringing contribution in relation to economic, environmental and occupational health benefits. (Santos et al (2012) by CEBDS [14])

Products may be more important in their usability phase contributing to the reduction of water and energy consumption if compared to the production phase of them. It can be verified in studies of the analysis of the life cycle in certain products. (Bruno et al (2009) cited in Faria; Pacheco [13])

Cardoso [2] argues that it is up to design to reflect more and more about the life cycle of the projected object, seeking to generate solutions that optimize factors such as the usability of non-polluting materials, efficiency of operation, reuse potential among others.

Connecting fiber, clothing and its user is the initial step so that even small changes in materials can be interpreted and visualized in users' behavior and products (Fletcher, [15]). For CETESB and UNEP [16], the concepts of Cleaner Production include the elimination of toxic raw materials and the preservation of energy and natural resources.

Roos [17], reports that in rectilinear knitting the fabric is produced in the form of panels, cloths or individual pieces. He also contemplates that this sector, when compared to other industrial segments, is considered as nonpolluting with solid waste, which basically consist of yarn and fabric fragments that other companies can make use of these for the realization of various products.

The phases of the knitwear development process are based on the type of machinery used and its own manufacture. Thus, when cutting using panel fabric, which is defined in a rectangle with measures of length and width that ensure the cutting of the garment generating the residue of knit, the Cleaning Production enters into this context directing this leftover raw material creating new products. The Fully Fashion method in turn cooperates with the Cleaning Production proposal. It consists in the reduction of stitches by modeling the clothing (body, neckline and armholes) in the own machinery of fabrication, consequently eliminating cuts and obtaining the readymade piece.

Decrease knitting is a process by which a continuous knitting product is obtained by reducing and increasing the calculated points mathematically and accurately, shaping the product to the end. According to Giannetti and Almeida [5], the substitution of materials, partial changes in the process and any changes that directly or indirectly help to reduce the environmental impacts make part of the 
Cleaning Production.

When clothing is in the finishing process it generates wastes of yarns in small quantities from each lot of color left inside the production. A way guided by the Cleaner Production would be the union of these mixed yarns, either by the composition or by color to obtain a new raw material that would become an elaborate and different product.

According to Ruthschilling et al. [18] it is done the union of surplus knitting yarns in garment machinery, where the implementation of a closed recycling cycle can be observed, which for Giannetti and Almeida [5] competes the reuse of the waste in the own process.

\section{Rectilinear Knitting}

\subsection{The Segment - Concept and History}

Sissons [19] and Pezzolo [1] Udale [20], assert the concept of knitting by weft where a single yarn is responsible for the construction of loops and these in turn are formed in the direction of the length of the fabric (warp) and in the width direction (weft), thus the knit is knitted along the warp and the weft of it offering to the fabric an elastic quality.

According to Pezzolo [1] knitting discoveries in Egypt prove that this method was known in the fifth century BC. For Sindmalhas [21] and Sissons [19], the oldest illustration dealing with the construction of a knitted garment painted by Meister Bertram is of the Virgin Mary in the 14th century producing a circular knitted fabric for Jesus. Both also claim that home-made manufacturing has become increasingly important over the years. The beginning of the sixteenth century is dated to the industry of knitting with machines according to Sisson [19].

It is estimated that the manual knitting took ten centuries to reach Italy, and thereafter has spread throughout Europe. Around 1488, in Great Britain, it was established the knitting technique in the production of hats. In 1550, in England, the first stockings of silk of knitting were created, and in 1561, queen Elizabeth I enchanted with the fineness and elasticity of them. The first manual weft knitting loom came only in 1589 , invented by Pastor Willian Lee (Sindimalhas [21]).

The fashion of women's and men's knitwear suffered a change in the late nineteenth and early twentieth century so sweaters, cardigans and other knitwear began to be used both for day and night mainly as sportswear. (Udale [20])

The growth of knitting is now very visible. Knitwear of various shapes, types and textures can be found in both women's and men's apparel as well as in children's clothing, due to the innumerous technological investments made in this segment.

Historical background showing succinctly the trajectory of fashionable knitwear:

Table 1. The trajectory of fashionable knitwear

\begin{tabular}{|l|l|}
\hline Year & \multicolumn{1}{|c|}{ Synthesis of fashionable knitwear } \\
\hline $\mathbf{1 9 0 0}$ & The amount of pieces of knitting used for sporting practices increases more and more. \\
\hline $\mathbf{1 9 1 0}$ & Golf leads women to the use of adapted knits of men's clothing. \\
\hline $\mathbf{1 9 1 6}$ & Jersey knitwear makes up women's swimwear. \\
\hline $\mathbf{1 9 1 7}$ & With the proposal of practicality the designer Chanel brings in her costumes the silk Jersey. \\
\hline $\mathbf{1 9 2 0}$ & Knitting sweater becomes more popular as well as colorful models (Fair Isle). \\
\hline $\mathbf{1 9 2 4}$ & Artificial silk stockings are more sought after, but they run and tear easily. \\
\hline $\mathbf{1 9 2 5}$ & Multicolored sweaters are combined with skirts and trousers. Wool hats are worn by women with practicality to ride a motorcycle. \\
\hline $\mathbf{1 9 2 7}$ & $\begin{array}{l}\text { The knitting is done by hand to increase the family income. } \\
\text { Elsa Schiaparelli's sweater (knitting) is successful and is the basis of her career. }\end{array}$ \\
\hline $\mathbf{1 9 3 0}$ & Knitwear is still used for the sport and especially the sweater. \\
\hline $\mathbf{1 9 4 1}$ & Lingerie and pantyhose take over the shops. \\
\hline $\mathbf{1 9 4 3}$ & The knitting stands out as being economically useful and represents the military service then. \\
\hline $\mathbf{1 9 5 0}$ & At the end of this decade the sweater is worn both short and large and these are accepted as fashionable in the next ten years. \\
\hline $\mathbf{1 9 6 0}$ & The knitting establishes itself in the fashion world. \\
\hline $\mathbf{1 9 7 0}$ & At the beginning of this decade, craft knitting once again stands out due to available materials. \\
\hline $\mathbf{1 9 7 5}$ & In the late 60's Missoni makes the machine knitting a sophisticated level never seen, with prints and blending patterns and stripes. \\
\hline $\mathbf{1 9 8 0}$ & The knitting reaches its peak; the knit are widely used in various patterns and becomes more and more popular. \\
\hline
\end{tabular}

Source: Adapted by the authors of Callan [22] and Blackman [23] 


\subsection{Simple Structure}

There is an extensive range of structures related to knitting, but they come from basic ligaments, one of them is the so-called simple knitting.

The knitted fabric of simple ligament according to Pezzolo [1] and Callan [22] is called jersey. This name originated from the place (Jersey Island, England) at the end of the 19th century, where thick sweaters were the first worn garments by fishermen.

The simple jersey is also called the half-knit by Tremelloni and Ceriani [24], Jones [25] and Udale [20]. It is understood as the fabric made in a single bed machine (one set of needles), and in turn has a different aspect with respect to the right side and the wrong side, which can be perceived, since the knitting stiches are visible in the fabric on the right side and is called stockinette stitch also seen as v-pattern and composing the smooth and soft fabric, and the curvy bump shape found on the wrong side of the fabric provides a rough and rugged surface due to the grouping of curvy and union of the knitting, and is called "tricot". This type of knitting can have a light or heavy characteristic, can break and then the stitch might move and also when cut tends to curl on the sides.

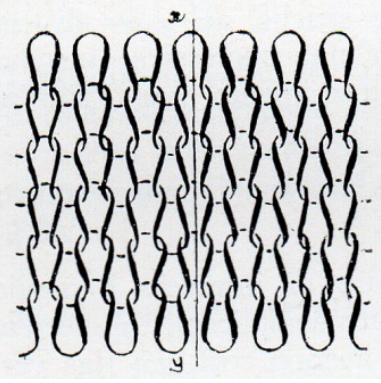

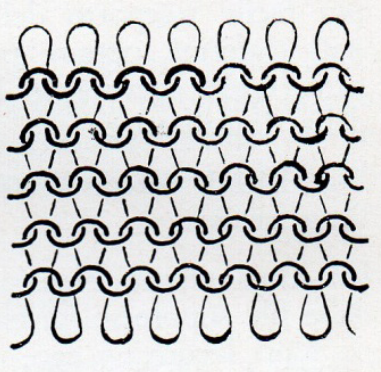

Source: Tremelloni and Ceriani [24]

Figure 4. The figure shows the right side (a) and the wrong side (b) of the half-knit fabric.

\subsection{Full Fashion}

Tremelloni and Ceriani [24] assert that the so-called full fashioned, also known as a diminished knitting, is carried out by a variation in the knit size (knit width) that approaches or moves away from the edge of the fabric as it increases or decreases the final needles doing the knit transport. Sissons [19] complements in relation to full fashion, it is a knit obtained in the segment of knitwear per weft and has as characteristic modeling finish presented in its entire selvedge.

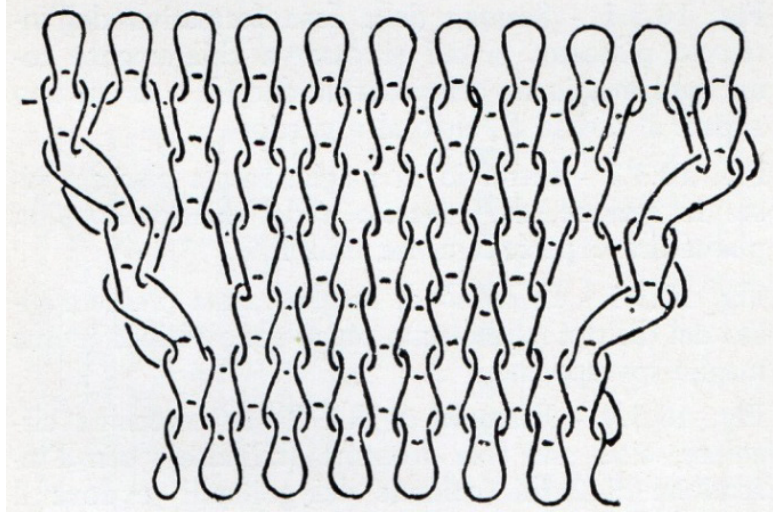

Source: Tremelloni e Ceriani [24]

Figure 5. Crossing in the increasing of a knit towards the right and left

This figure according to Tremelloni and Ceriani [24] shows the characteristics of the knit when the work is increased towards left and right. Thus it is possible to observe the formation of a small hole where the transport happens. It is due to the fact that the yarn forms a handle on the empty needle. Sissons [19] assures that the increasing method consists in the addition of new stitches in the direction of the width of the knit.

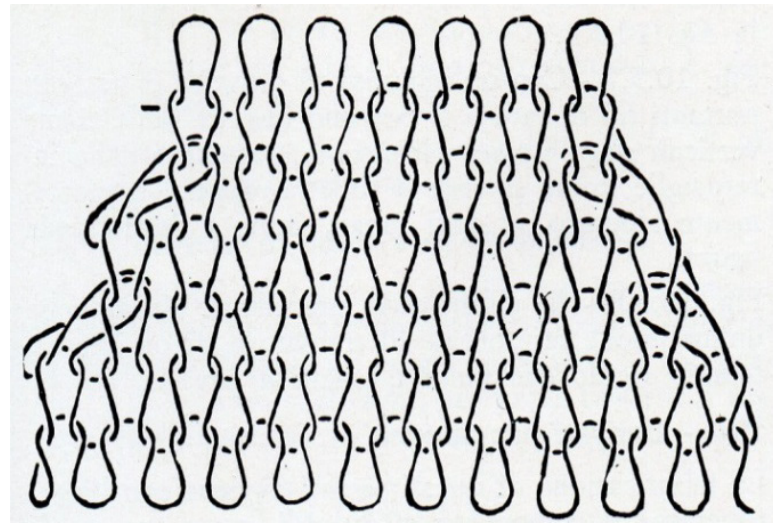

Source: Tremelloni e Ceriani, [24]

Figure 6. Crossing in the decrease of a knit ending towards the center

The characteristics of the diminished knitting can be seen in figure 6 , where the decrease of the knit starts on the right and left side of the knit ending towards the center of the mesh. (Tremelloni and Ceriani, [24]). For Sissons [19] it consists of the method of decreasing the knit width where two or more stitches are woven together.

Thus the diminished knitting has as its main character the variation of dimensional direction forming edges both solid and wide, and for that reason cancels a coarse seam, which would be necessary to close a piece of heavier weight. (Tremelloni and Ceriani, [24]) 


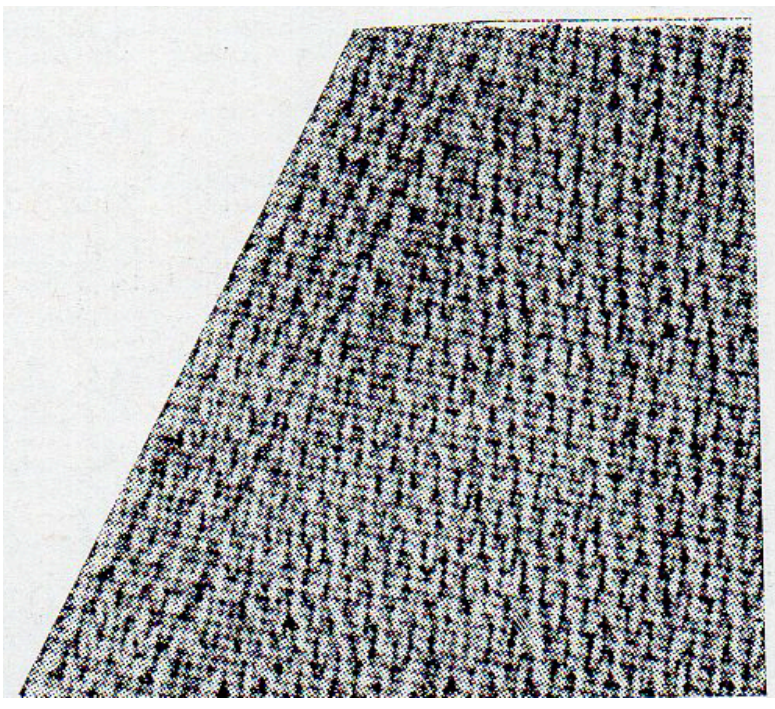

Source: Tremelloni and Ceriani [24]

Figure 7. Knit sample of a decreased structure

Figure 7 shows the sample of a dimension made with a rectilinear machine, using four needles forming rows on the edge. Source: Tremelloni and Ceriani [24]

\subsection{Machinery}

As for knitting machines, two categories can be considered according to Udale [20] and Sissons [19]: The so-called single bed machine which contains a single set of needles and is normally used to manufacture a simple and basic knit fabric where the visualization of the fabric is better and easier to understand. The other is the double bed with two sets of opposing needles, which offer greater flexibility where it is possible to produce a double knit or ribbing and still allows innumerous possibilities of other points. Due to sophistication and evolution in the knitting industry, Sissons [19] completes that there are machines with four beds that offer different sewing today as the thickness of yarns and patterns. Such machines need investment and programming system, but accomplish complete clothing.

Sissons [19], reports that in 1970, the newest machine Shima Seik was responsible for bringing the concept of whole parts (seamless). A decade later (1980), since its launch, the company had already computerized its machinery completely.

Ganzer et al. [26], complements that it can detect the deployment of rectilinear machines that work with technology (decreased), readymade part, with the purpose also to adhere to environmental management issues, since this process may even take more time in Its production, but it has the advantage of not generating leftovers of materials and the clothes are directly sent to the seaming.

Roos [17] asserts that the increase in the quality of the knitting product is related to the new technologies inserted in the production, one of them is the insertion of electronic machinery, that avoid cuts in the pieces, reducing the labor and avoiding the waste of raw material. Thus the manufacturing process has been modified in an accelerated way, and this equipment that manufactures the finished part has been intensified more and more in this segment.

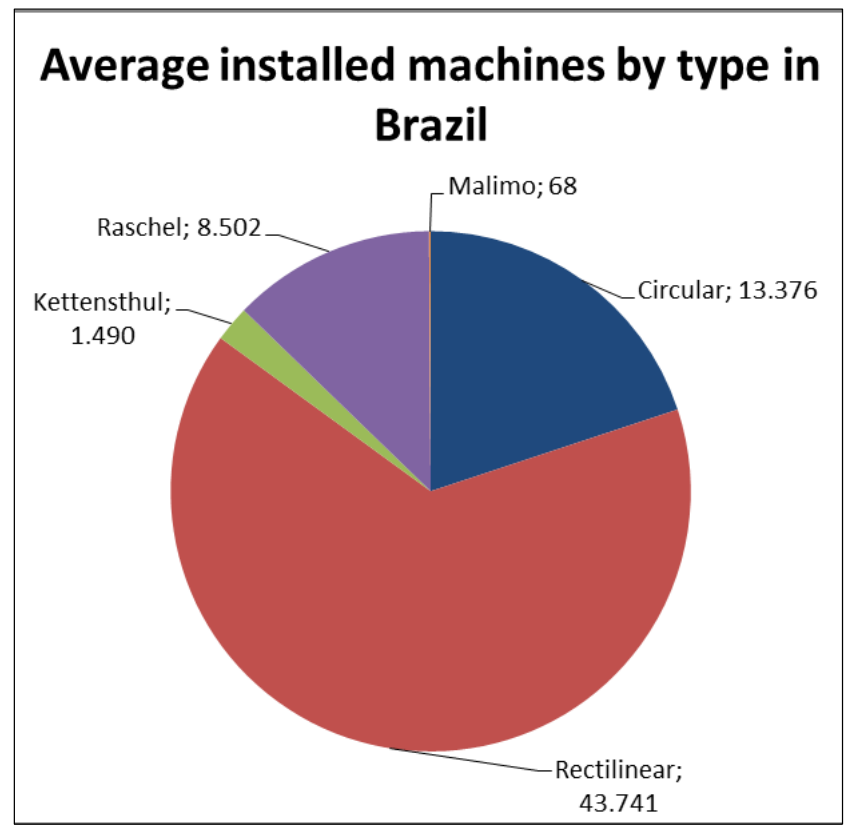

Source: Adapted by the authors of IEMI [11]

Graph 1. Average installed machines by type in Brazil between the years 2008 to 2012

As can be seen in the graph above, the average of the rectilinear machines installed in Brazil between the years of 2008 and 2012 represent the great majority, equivalent to 43,741 . It indicates a considerable growth in this segment of the textile chain.

\section{Fashion Clothing Manufacture}

Fashion clothing manufacture refers to the same segment of the garment industry; however, it emphasizes the very procedures and processes of the confection and production. Thus, fashion clothing manufacture is an expression that considers the method and the production to reach a final product. (MENDES [27])

The clothing industry is understood by Mendes [28] from products manufactured on a large scale or with a wide distribution, which can be considered commodities, or fashion products that have: reduced quantity by model, short life cycle, variation and differentiation extended.

\subsection{Manufacturing of Rectilinear Knitting}

In a knitting industry the main focus is the manufacture of knitted fabrics, which in turn are originated through the use of the raw material known as yarn. It is a vast field and contains mostly clothing in constant development for 
women, men and children as well as it can also be found in decoration. (AQUINO [29]).

Gatti [30] asserts that knitting products are currently inserted in many areas besides clothing, and their usability is due to some of their properties, such as strength, trim, soft appearance, freedom of body movements due to their elastic shape, ease in maintenance and thermal properties, among other factors.

EI Mogahzy [30] deals with applications in this segment focused on technical articles, for they are widely used in the medical sector for bandages, artificial heart valves, implants and several others. (GATTI [30])

The weft technology is very diversified and widespread. Its attribution is almost a quarter of the production of fabrics for clothing, the weft machinery of this sector has suitability for small producers, due to some factors such as cost, speed and versatility, among others. (GATTI [30])

According to Mendes [27], when comparing the knit fabric with the flat fabric, it is known that its cost ends up being lower than the flat fabric, because production is faster in knitting. It also emphasizes that these ones have great market acceptance because they are practical and versatile.

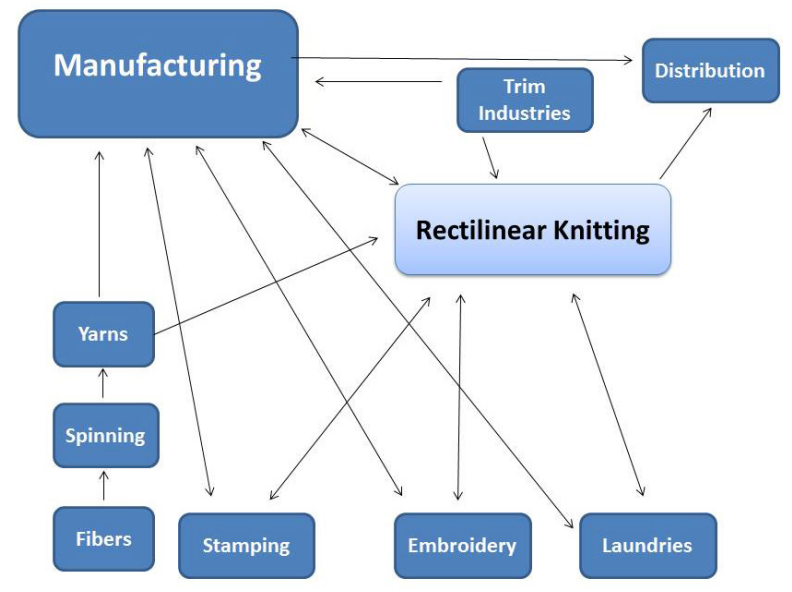

Source: Adapted from Mendes [27]

Figure 8. Complete textile chain and its business network.

According to Mendes et al. [27] the textile chain should be presented by a business relationship through a network formed in a complex way that must pass from the suppliers of raw material to the distributors of the final product. We can observe that Rectilinear Knitting is inserted in this chain in a singular way (figure 8), for it is interlaced to all the links of this chain. Roos [17] adds that the industrial sector of rectilinear knitting, in its turn is inserted in the textile chain as well as in the Brazilian textile industry, showing that its links of processes are really interconnected.

The Rectilinear Knitting industry is considered to be very old, but today it is intense and fascinating, offering creative diversity. Unique effects on yarns are achieved by adjustments that blend colors and textures. These particularities can be added to fiber in the spinning steps. A knit piece can receive color and durability through embroidery. Decorations can be made using various ribbons and yarns emphasizing the garment in light, rich and delicate details. Other types of improvement can be considered according to the character of the knit obtained, without plush and firmly constructed can make a stamping viable. (SISSONS [19])

The quality in the knitted fabric can also be changed through finishing processes performed in laundries, where softeners can be used to improve the handling of clothes, as well as high temperature washes and the use of friction allow to felt the woolen fabric, for example, resulting in an effect of the fibers melting and assigning the knit a higher density and a lower elasticity. (UDALE [20])

For Roos [17] the distribution process is linked to the type of article made, the machinery used and the region where it is inserted. Therefore, its distribution is related to the domestic market with sale under order, or sale in a prompt delivery, linking this for shopkeepers and / or wholesalers.

\section{Analysis and Discussion}

Nowadays, the concepts about cleaner production tools are based on the theoretical and bibliographic references as well as in related documentary research. All in all, there are some points to be highlighted.

In relation to the applications of cleaner production practices in the rectilinear knitting sector, it is possible to think of this process from the raw material that is usually used for mixed composition yarns, since the fibers that form them are often abrasive in the environment and difficult to decompose. Instead of using these ones you can direct the work with yarns composed of natural fibers or eco-fibers. Table 2 shows other applications of cleaner production practices.

Table 2. Some applications of cleaner production practices in rectilinear knitting

\begin{tabular}{|c|c|c|}
\hline Cleaner Production & Stages of the process & Traditional methods \\
\hline Natural composition yarns & - Raw material & Mixed composition yarns \\
\hline Fully Fashion & Fabrication & Panel fabric cutting \\
\hline $\begin{array}{c}\text { Generation of Raw } \\
\text { material }\end{array}$ & Cutting & $\begin{array}{l}\text { Generation of wastes } \\
\text { (fabric) }\end{array}$ \\
\hline $\begin{array}{l}\text { Union of mixed yarns to } \\
\text { obtain a new raw material }\end{array}$ & Finishing & $\begin{array}{l}\text { Generation of wastes } \\
\text { (yarns) }\end{array}$ \\
\hline
\end{tabular}

Source: Elaborated by the author. 
For CETESB and UNEP [16], the concepts of cleaner production include the elimination of toxic raw materials and the preservation of energy and natural resources. For Fletcher [15] to interconnect fiber to clothing, and to its user is the initial step even for small changes in materials in order to be interpreted and visualized in users' behavior and products.

Roos [17] reports that in rectilinear knitting the fabric is obtained in the form of panels, cloths or individual pieces, and also contemplates that this sector, when compared to other industrial segments, is considered as nonpolluting in relation to solid waste, which, for example, consist basically of fragments of yarns and fabrics, and that other companies can make use of them for the realization of numerous products.

The phases of the knitwear development process are based on the type of machinery used and its manufacture. Thus, when cutting using knit fabric panel, which is defined in a rectangle with measures of length and width that ensure the cut of the clothes, the excess of knit is generated. The Cleaner Production enters in this context directing this leftover material, creating new articles. The Fully Fashion method, in turn, cooperates with the Cleaner Production proposal, since it consists in the reduction of stitches by modeling the clothing (body, neckline and armhole) in the own fabric machinery, consequently eliminating cuts and getting the finished or semi-finished piece.

Softened (decreased) knit is a process by which a continuous knitting product is obtained by reducing and increasing the calculated stitches mathematically and precisely, shaping the product to the end. According to Giannetti and Almeida [5], the substitution of materials, partial changes in the process and any changes that directly or indirectly leads to the reduction of environmental impact are part of the Cleaner Production (MOTTA; CONTI [31]).

When clothes are in the finishing process it generates wastes of yarns. From the moment that small quantities of each lot of color are left within the production, one path guided by the cleaner production would be the union of these mixed yarns, either by the composition or the color to obtain a new raw material that would become an elaborated and different product.

According to Ruthschilling et al. [18], the union of surplus knitting yarns is made in the garment's own machinery, where it can be observed the implementation of a closed recycling cycle that, for Giannetti and Almeida [5], deals with the reuse of the waste in the process itself.

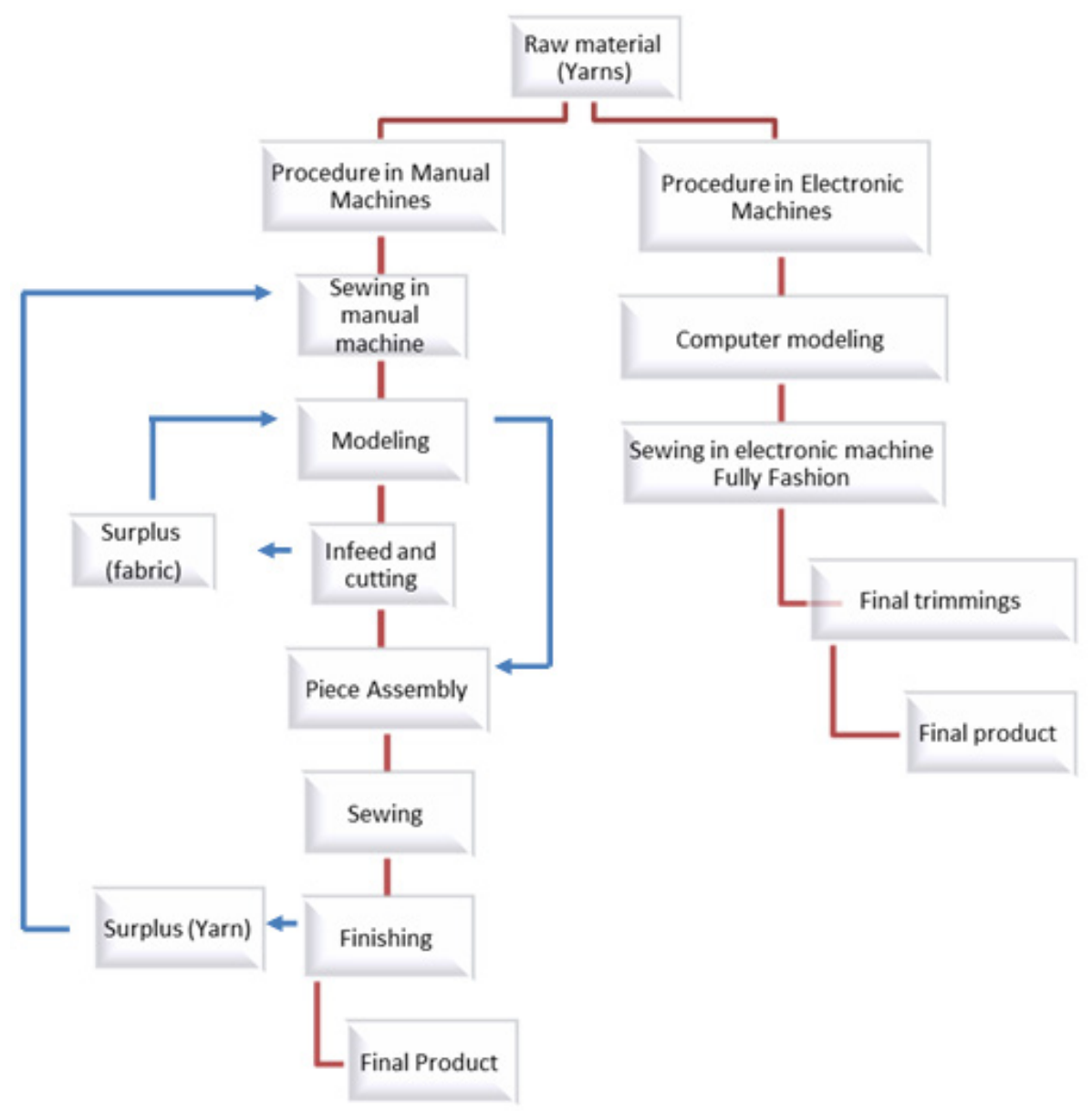

Source: Elaborated by the author.

Figure 9. Rectilinear knitting processes involving manual and electronic machines. 
Based on different machines (manuals / fully fashion), highlighting the phases where the reduction of waste can be visualized through the processes, it is possible to emphasize both in the traditional method and in the contemporary method where there is the possibility of minimizing textile waste. So in the manual process comes through the workmanship of the operator, since in the other process it happens attached to the own technological machinery.

\section{REFERENCES}

[1] D. B. PEZZOLO. Tecidos História, Tramas, Tipos e Usos. São Paulo: Editora Senac São Paulo, 2007.

[2] R. CARDOSO. Uma introdução a história do design. São Paulo. Blucher, 2008.

[3] A. B. JABBouR, L. S., C. J. JABBOUR, C. Gestão ambiental nas organizações. São Paulo: Editora Atlas S.A., 2013.

[4] C. ANACLETO, et al. Ecoeficiência e Produção Mais Limpa: Uma análise das publicações em quatro periódicos brasileiros da Engenharia de Produção. Sistemas \& Gestão: Revista Eletrônica, Universidade Federal de Santa Catarina - UFS, 2012. Disponível em: <http://www.revistasg.uff.br> Acesso em 15 mar. 2014.

[5] B. GIANNETTI, F. C. M. B. ALMEIDA, V. Ecologia Industrial: Conceitos, ferramentas e aplicações. São Paulo: Editora Edgard Blücher, 2006.

[6] R. A. LUKEN, et al. A 20-year retrospective of the National Cleaner Production Centres programme. Journal of Cleaner Production, 2015. Disponível em:

$<\mathrm{http}$ ://dx.doi.org/10.1016/j.jclepro.2015.07.142> Acesso em 18 ago. 2015.

[7] R. DIAS. Eco-inovação: caminho para o crescimento sustentável. São Paulo: Atlas, 2014.

[8] SENAI. Produção mais limpa em confecções. Publicação elaborada com recursos do projeto Publicação Casos de Sucesso em Produção mais Limpa sob a orientação, coordenação e supervisão do Centro Nacional de Tecnologias Limpas - CNTL SENAI-RS. 2007.

[9] M.SENAGA; J. JORGE. Pequenas empresas e universidades são incentivadas a adotar e disseminar a prática da Produção Mais Limpa. 2010. Disponível em:< http://www.cetesb.sp.gov.br/noticentro.htm> Acesso em 16 jun. 2014.

[10] SEBRAE (Serviço Brasileiro de Apoio as micro e pequenas Empresas). Desenhar não é o bastante para empreender em moda. Recife, 2014. Disponível em:

$<$ http://www.sebrae.com.br/Sebrae/Portal\%20Sebrae/UFs/ $\mathrm{PE} /$ Anexos/perfil $\% 20 \mathrm{de} \% 20 \mathrm{neg} \% \mathrm{C} 3 \% \mathrm{~B} 3 \mathrm{cios} \% 20 \mathrm{de} \% 20 \mathrm{~m}$ oda.pdf $>$ Acesso em: 18 dez 2015.

[11] IEMI. Instituto de Estudos e Marketing Industrial Itda.
Relatório Setorial da Industrial Têxtil Brasileira. São Paulo BR. V1 13 n $^{\circ} 13$ de agosto de 2013

[12] W. F. ZONATTI, et al. Retalho Fashion: Destinação Adequada dos Resíduos Têxteis do Polo Confeccionista do Bairro Do Bom Retiro (São Paulo/Sp) Como Instrumento de Planejamento Ambiental. $2^{\circ}$ Congresso Cientifico Têxtil de Moda - CONTEXMOD. São Paulo, 2014.

[13] F. FARIA, P.; , E. B. A. PACHECOV. Experiências com Produção Mais Limpa no Setor Têxtil. Revista de Design Inovação e Gestão Estratégica - REDIGE, v. 2, n. 1, 2011

[14] CEBDS - Guia da Produção mais Limpa, Faça Você Mesmo, 2008. Disponível em:

http://www.pmaisl.com.br/publicacoes/guia-da-pmaisl.pdf, Acesso em 07 jun. 2016.

[15] K. FLETCHER; L. GROSE, Moda \& Sustentabilidade: Design para mudança. São Paulo: SENAC, 2011.

[16] CETESB; PNUMA, A produção mais limpa e o consumo sustentável na América Latina e Caribe. São Paulo, 2005.

[17] D. B. ROOS, Bretz. O setor industrial de malharia retilínea de Caxias do Sul: um estudo sobre o aglomerado de pequenas empresas. Dissertação (Mestrado) - Curso de Programa Ciências Econômicas, Universidade Federal do Rio Grande do Sul, Porto Alegre, 2001.

[18] E. A. RUTHSCHILLING, et al. Upcycling of rectilinear kniting yarn in sustainable fashion products. In: $2^{\circ} \mathrm{CIMODE}$, 2014, Milão. Anais do $2^{\circ}$ CIMODE, 2014.

[19] J. SISSONS. Fundamentos de design de moda: Malharia. Tradução técnica: Bruna Pacheco. Porto Alegre: Bookman, 2012.

[20] J. UDALE, Fundamentos de design de moda: Tecidos e Moda. Tradução: Edson Furmankiewicz - Porto Alegre: Bookman, 2009

[21] SINDIMALHAS. Tecidos de Malhas, 2014. Disponível em $<$ http://www.sindimalhas.com.br/estudos> Acesso em 16 de nov. de 2014.

[22] G. O. CALLAN. . a da Moda. São Paulo: Companhia das Letras, 2010.

[23] C. BLACKMAN. 100 anos de moda. Trad. Mario Bresighello. São Paulo: Publi Folha, 2012

[24] A. TREMELLONI; L. CERIANI. Manual e Técnico per L'Industria della Maglieria v.1 e v.2 Milano: Industria Pubblicazioni Audiovisivi, 1975.

[25] S. JONES, J. Fashion designer - manual do estilista. São Paulo: Cosac Naify, 2005.

[26] P. GANZER, P. et al. Análise de gestão ambiental de uma indústria de malhas na Serra Gaúcha. Repositório institucional da Universidade Federal do Rio Grande - RI FURG, 2012. Disponível em

$<$ http://repositorio.furg.br/handle/1/5664> Acesso em 13 de nov. de 2014.

[27] F. D. MENDES; J. SACOMANO; J. FUSCO Redes de empresas: a cadeia têxtil e as estratégias de manufatura na indústria brasileira do vestuário de moda. $1^{\circ}$ ed.São Paulo: 
Arte e ciência, 2010.

[28] F. D. MENDES. Cadeia Têxtil e as Estratégias de Manufatura na Industria do Vestuário de Moda. Dissertação (Mestrado em Engenharia de Produção) Universidade Paulista - UNIP, São Paulo, 2006.

[29] AQUINO, M. S. Apostila de métodos e processo de manufatura de malha I. Departamento de Engenharia Têxtil,
Universidade Federal do Rio Grande do Norte. 2008

[30] R. GATTI. Tessuto tra le due e le tre dimensioni. Strumento per una selezione intuitiva e consapevole dei tessuti tridimensional. Politecnico di Milano, Scuola del Design, CdLM Design \& Engineering, 2014.

[31] M. MOTTA,; G. M. CONTI. Knit design contempory scenarios. II CIMODE, 2014. 